\title{
The Political Dimension of the Performance Jeanne d'Arc au bûcher [Joan of Arc at the Stake] in the Janáček Theatre, Brno in 1969
}

\author{
Helena Spurná
}

\begin{abstract}
16 January 1969 was an important day for Czechoslovakia: Jan Palach, a student at the Faculty of Arts, set himself on fire next to the statue of St. Wenceslas in Prague. The artistic scene reacted to the incident through several works. The performance of Arthur Honegger's stage oratorio Jeanne d'Arc au bûcher in Janáček Theatre in Brno was one of them. The article introduces political circumstances and artistic form of the performance, summarizing photos, materials from the legacy of the director Miloš Wasserbauer, various reflections and reviews. For the author of the article the importance of the performance lies in the fact that the Brno opera presented a work which had not been performed on the Czechoslovak stages before. The primary reason for this was the undoubted staging and interpretation demands connected with Honegger's monumental hybrid creation. The fact that Brno put Jeanne d'Arc au bûcher to their repertoire at the time of the revolutionary political changes in Czechoslovakia provided the story of Joan of Arc with an up-to-date message.
\end{abstract}

\section{Keywords}

Arthur Honegger, Jeanne d'Arc au bûcher, Janáček theatre in Brno (1969), political context of the performance, critical reactions

This study came about as part of the research project The Generation of Miloš Wasserbauer, the Theatre Director, and Progressive Dramaturgy of the State Theatre in Brno, supported by the Czech Science Foundation (No. GA15-06548S). 
The end of the 1960s represents one of the most dramatic periods in Modern Czech or actually Czechoslovak history. The invasion of the armies of the Warsaw Pact on 21 August 1968 brought an end to the Prague Spring. The period of so-called Normalization, which was marked by, amongst other things, the renewal of censorship and the suppression of earlier liberal reforms, ensued as of April 1969.

16 January 1969 was an important day for Czechoslovakia at the time when Jan Palach, a student of the Faculty of Arts at Charles University, set himself on fire next to the statue of St. Wenceslas in Prague. This was not of course the only case of this form of protest involving self-immolation. Palach's symbolic gesture shocked not only the domestic public but also the foreign one. ${ }^{1}$ Crowds of people participated in the funeral, thereby expressing their resistance to Soviet occupation and to the loyalist position taken by the domestic political representation in relation to Moscow.

The artistic scene also reacted to the incident. It became a theme, for example, in the drawings of the artist Jiří Sozanský. ${ }^{2}$ The sculptor Olbram Zoubek cast his death mask with a determination to artistically depict Palach's final service. After the Velvet Revolution in 1989, a metal copy was created which is currently situated on the building of the Faculty of Arts. An LP record was recorded under difficult conditions over the course of one night in the year 1969 entitled Where the World Ends - In Memory of Jan Palach. It never found its way into distribution. Poetic verse about the incident was recited by Czech actors, including Jan Tříska, who emigrated to the United States in the year 1977. ${ }^{3}$ The film makers Stanislav Milota and Milan Peer created short documentary films. Milota's film essay Jan 69, recorded during Palach's funeral and including the music of Antonín Dvořák and Leoš Janáček, was found in a film archive after the year 1989. The music scene also reacted to the incident. The most interesting composition was a choir cantata Ignis pro Ioanne Palach by Jan Novák who had also emigrated after the year 1968. He composed the piece in Denmark. The premiere was in the Rudolfinum on 15 April 1969 and a commemorative recording was made in Munich in the year 1970 by Rafael Kubelik. During the recording of the LP record Where the World Ends, an organ improvisation of the renowned Czech composer Petr Eben came about. Several composers immediately reacted in Brno. Two works, inspired by Palach's act, were released on 29 January 1969: Tryzna za Jana Palacha (Memorial for Jan Palach) by Josef Berg and a composition entitled 16. 1. 1969 by Alois Piňos. Another Brno composer Evžen Zámečník created the piece Elegia per Jan Palach [Elegy for Jan Palach] at the same time. ${ }^{4}$

1 Student demonstrations took place in Rome, Milan, Vienna and additional Western European cities. Members of parliament in Copenhagen announced two minutes of silence. Palach's act was also commemorated in similar fashion in Council of Europe. Cf. (YANNAKAKIS 2009: 177).

2 The National Museum organised an exhibition of the art work of Jiří Sozanský entitled 1969: the Breakthrough Year in 2016. The artist's large-format paintings, assemblages, collages and photography inspired by Palach's act were on display.

3 A radio programme came about on the basis of the record which was again never played.

4 The response in Czech classical music to the self-immolation by Jan Palach has been dealt with in detail by Eva Nachmilnerová. Cf. (NACHMILNEROVÁ 2009: 223-227). 


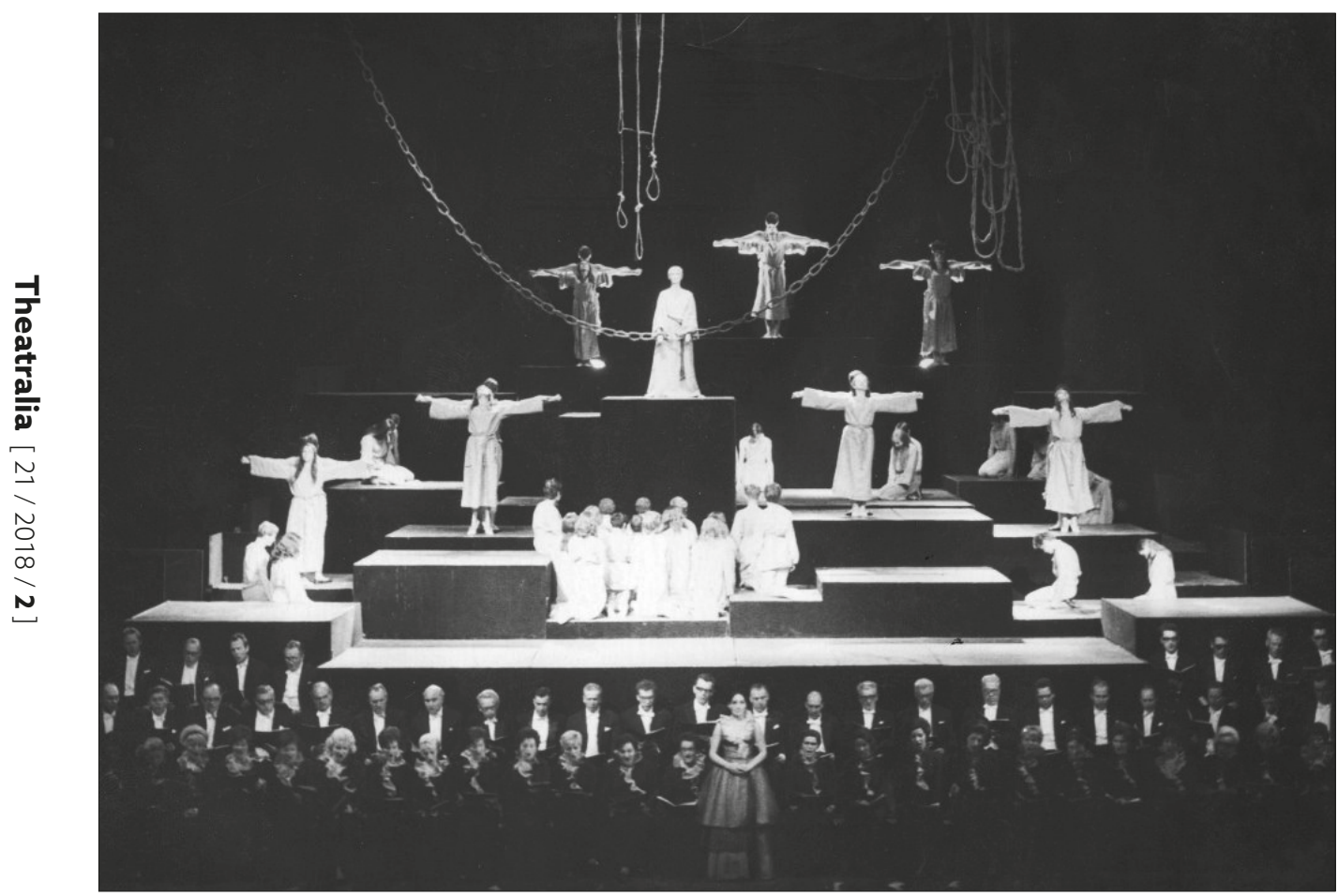

Fig. 1: A. Honegger: Joan of Arc at the Stake. National Theatre in Brno, 1969. XI. scene: 'The Burning of Joan of Arc'. The archive of National Theatre in Brno (Archive NTB).

The concert performance of Arthur Honegger's stage oratorio Jeanne d'Arc au bûcher $(1935)^{5}$ in the Rudolfinum concert hall in Prague was a significant event linked with the first anniversary of the death of Jan Palach. This first anniversary came about under the strict supervision of the State Police. Any form of solidarity with Jan Palach was a possible crime. This consequently consisted of an artistic act of a quite heroic character. The piece was performed by the Czech Philharmonic Orchestra conducted by Václav Neumann on 12 and 13 February $1970 .{ }^{6}$ This was primarily the effort of the dramaturg of the philharmonic orchestra Ivan Medek who was already a problematic figure in the eyes of the regime. The concert of Honegger's piece was consequently his last gasp as he was fired from the job afterwards. $^{7}$ The inclusion of Jeanne d'Arc au bûcher into the repertoire came about

5 The dramatic oratorio in a prologue and 11 scenes, adding speaking roles and actors, was set to a libretto by Paul Claudel and premiered on 12 May 1938 in Basel, with Ida Rubinstein as Jeanne (conductor Paul Sacher). The political circumstances of the time had an impact upon the beginnings of this often performed concert piece on various stages in Europe: the performance in Orléans, which took place in May 1939, involved racist attacks against the Jewish origin of the main performer.

6 The concert was even recorded for the radio, but the recording had to be erased.

7 Medek later became one of the signers of Charter 77, editor for Voice of America and after the 'Velvet Revolution' office manager for President Václav Havel for several years. 
more or less behind the back of the political establishment. When those in power learned that the cantata was to be performed upon the occasion of the anniversary of the death of Jan Palach, there was a great deal of commotion. The concert was originally planned for the end of January, that is in the month when Jan Palach died. The date had to be shifted and no one was allowed to find out why the change came about. The concert was nevertheless completely sold out and everyone was very much aware of the manifestation character of the event; everyone knew what was behind it. (MEDEK 2005: 64-65)

It would be relevant here to recall the wider historical and socio-cultural context behind Palach's act and his martyrdom. The act of self-immolation represents a theme in and of itself which was well-known in the Czech environment. Similarly, as with Joan of Arc's condemnation for witchcraft and heresy, there were actual events from history in the Czech Lands, similarly as in France, Germany, Switzerland or in the Netherlands, involving witch trials in the seventeenth century. Jan Hus, who was burned at the stake in the year 1415 in Constance in Switzerland for his criticism of the Catholic Church, ranks among the greatest martyrs in Czech history. One should recall that Hus played an important role in the construction of a new class-based interpretation of history after the rise to power of the Communists in the year 1948 and during the 1950s. The most well-known film about Jan Hus from the year 1954 actually still has an impact upon our memory. It was a typical propaganda film. Hus was presented in it as the leader of an uprooted people and a warrior struggling for social justice. (In order to be fair to the director of the film Otakar Vávra, he also made a film in the year 1969 about witch trials in the Czech Lands which amounted to an analogy to the monstrous trials of the 1950s. The horrors involved actually began to be known to the public in the 1960s.) The events around the year 1968 radically changed the earlier perspective on previous history. The theme of immolation received a new dimension with Palach, becoming politically unacceptable. There were also logically concerns related to the threat of crowd hysteria. The picture of Jan Hus once again emerged in connection with Palach who even apparently expressed that he wanted to imitate Hus by means of his decision and finally became a martyr in the eyes of the public (evidence of this is a song by Francesco Guccini Primavera di Praga, in which the words 'Jan Hus Burned Once Again at the Stake' resound).

In relation to the Prague staging of Honegger's celebrated opus, one tends to forget that the work was actually performed earlier in Brno, and the Czechoslovak premiere on the stage of the work Jeanne d'Arc au bûcher took place in Janáček Theatre in Brno on 27 June 1969. Jeanne d'Arc au bûcher was performed, in a translation by Karel Kraus, as part of one evening with Schönberg's Erwartung (Expectation). ${ }^{8}$

8 The staging of Honegger's work was under preparation in the Brno opera as early as the 1960/61 season, when it was supposed to be performed with the opera Ariadna (Ariane) by Bohuslav Martinů. Apparently, this did not finally happen for organizational reasons. Václav Nosek stated in an interview for the daily Rovnost that Cocteau's interpretation of the story of the French hero from the Hundred Years' War excited him equally as the partnership of Martinů-Neveux and their modern perspective of classical material. See 
The director was a celebrated figure of opera directing of the 1960s, Miloš Wasserbauer.

When Jeanne d'Arc au bûcher was performed in Czechoslovakia in the 1960s, Janáček Theatre in Brno was actually the most progressive opera theatre in the country at the time. It was distinct from the National Theatre in Prague in terms of presenting Janáček's works and the operas of Bohuslav Martinů. For example, in the year 1958, the world premiere of Janáček's opera Fate took place there. There was also the Czechoslovak premiere of Martinů's Greek Passion here in the year 1962 (this was a little less than a year from the world premiere of the opera in Zurich). Due to its bold dramaturgy, Brno became the site for additional Czechoslovak premieres of twentieth century operas. ${ }^{9}$ Worthy of mention are, for example, Prokofiev's opera The Fiery Angel (premiered in 1963), the opera Danton's Death by Gottfried von Einem (1966), Gershwin's Porgy and Bess (1968), The Nose by Dmitri Shostakovich (1973), The Condemnation of Lucullus by Paul Dessau and with the libretto of Bertolt Brecht (1974). Particularly interesting was the performance of Berg's Lulu in 1972 which was viewed as unsuitable in terms of theme in Prague. A unique item on the Czechoslovak opera theatre scene was the experimental stage entitled Miniopera, founded in 1969. This was the site of original opera works, as well as, for example, Stravinsky's L'Histoire du soldat (1969) or, for the first time in the country, the opera minutes by Darius Milhaud L'enlèvement d'Europe, La délivrance de Thésée and L'abandon d'Ariane (1972). Another positive feature of Brno opera of the 1960s and 1970s was the employment of staging approaches which were viewed as unconventional in the domestic context. There was an attempt at building upon the uninterrupted continuity with the poetics of inter-war avant-garde and at adapting opera staging to non-illusionist stylisation.

The events in opera theatre went hand in hand with dramatic theatre in Brno which also experienced a golden age in the 1960s. At a time when other official Czech theatres were dominated by realism as the officially accepted style, Brno emphasized antiillusive and metaphorical theatre. The program of the Brno theatre celebrated theatre as artificial reality and had a preference for poetic parable as opposed to direct depiction. The Brno theatre scene also introduced new interpretations of political and social engaged theatre which was in conflict with the canon. ${ }^{10}$ While in Prague or in other parts of Bohemia this came about with a certain reservedness, it was more

(HEERENOVÁ 1969). We do not know with certainty why the choice for the later version specifically involved Schönberg's monodrama. The manuscript notes by the director of the staged evening Miloš Wasserbauer indicate, however, that the link between Jeanne d'Arc au bûcher and Ariane was perceived as clearly more appropriate in terms of staging, it being a similar theme involving 'the human struggle for freedom'. See the director's notes to the staging, the legacy of Miloš Wasserbauer, Department of Theatre History of the Moravian Museum in Brno, carton no. 280.

9 I have analysed the dramaturgy of Brno opera of the 1960s and 1970s in detail, with Šárka Havlíčková Kysová in our study 'Dramaturgická východiska opery Státního divadla v Brně v době působení Václava Noska a Miloše Wasserbauera' [The Dramaturgy of the State Theatre Brno under Václav Nosek and Miloš Wasserbauer]. See (HAVLÍČKOVÁ KYSOVÁ and SPURNÁ 2016: 212-227).

10 The work of Bertolt Brecht, who began to influence domestic scenic realism as of the year 1956, played a key role here. 


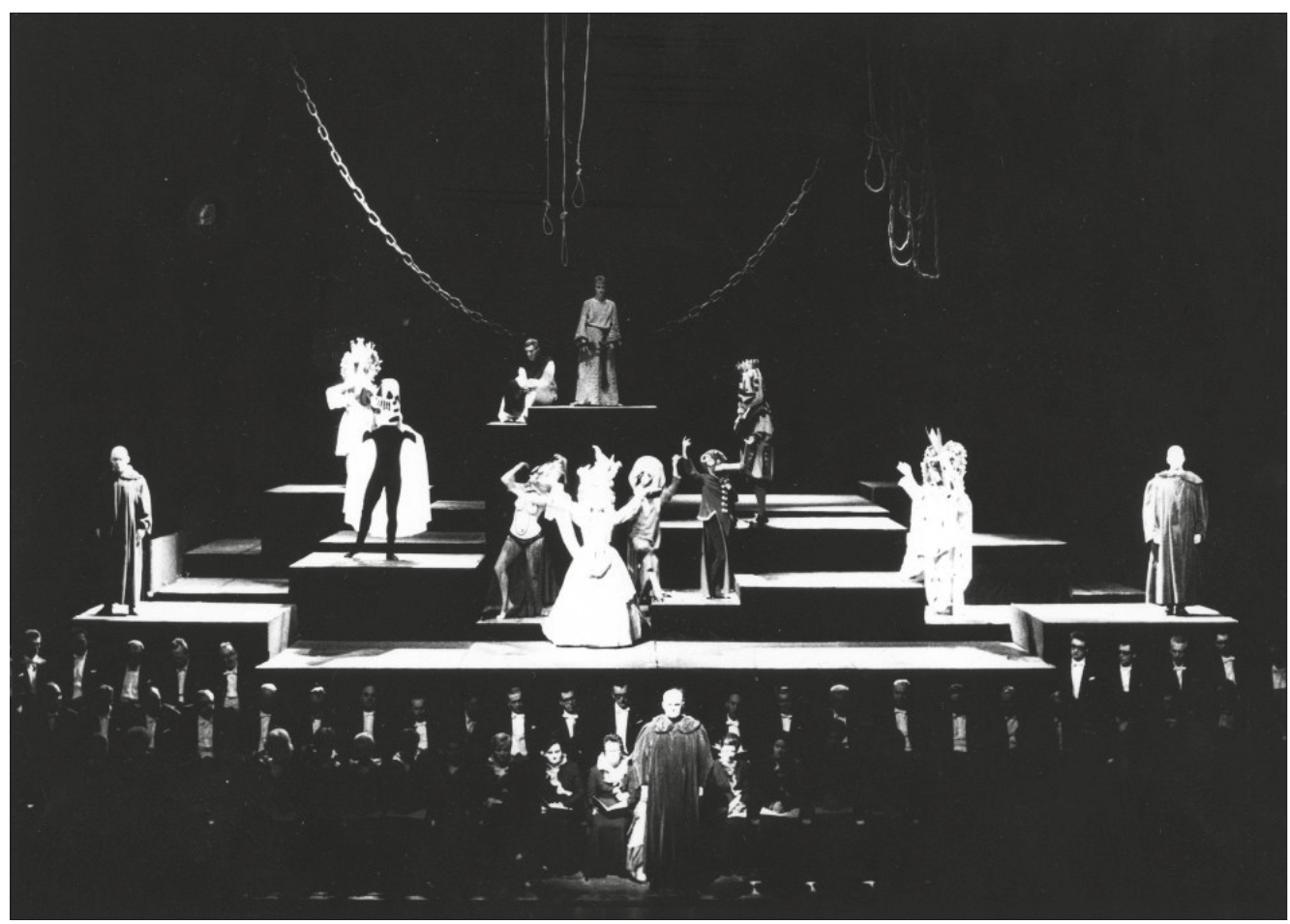

Fig. 2: A. Honegger: Joan of Arc at the Stake. National Theatre in Brno, 1969. IV. scene: 'Joan Given Up to the Beasts'. Archive NTB.

open and more program-like in Brno. The line of political theatre did not come about without a link to Soviet theatre avant-garde or Rolland's People's Theatre. ${ }^{11}$ The struggles with the censorship bodies were demanding and only certain pieces were successfully pushed through out of the planned titles. Opera, due to its highly stylized form which can soften any kind of political content, did not face such extensive censorship. Of course, the radical modernity of the dramaturgy and the staging method can be viewed as a political issue as by means of provocation it calls into doubt the audience and listening customs of the traditional opera public. A number of operas, however, acted as provocation merely from a thematic perspective. Even without any particular intention, operas such as The Nose, Wozzeck or The Condemnation of Lucullus, as recalled by certain participants, live on as a reference to the social and political atmosphere of the Normalization era. This is the way in which the staging of From the House of the Dead from the year 1974 was, for example, spoken about. It is known that Janáček's original conclusion had a pessimistic sound. After Gorjančikov is released from prison, the guard drives the other prisoners back into their cells. Later changes added an optimistic aspect in the form of the celebration of freedom. The return to Janáček's original

11 In more detail on the program of Mahen Drama Theatre in the 1960s, compare the study by Martina Musilová (MUSILOVÁ 2008: esp. 86-92). 
in a staging from 1974 had a truly dreary feeling, particularly when the director Václav Věžník actually emphasized the brutality of the guards which the prisoners were faced with.

Let us return, however, to Jeanne d'Arc au bûcher in Brno. It is apparent that Honegger's work was provocative, first and foremost because of its political content; the placement of the work into the repertoire shortly after the self-immolation of Jan Palach was clearly courageous and as will be mentioned later, the message had its intended impact. The unconventional aesthetic form also represented a certain kind of politics. This work, linking the genre of opera with an oratorio and symphonic cantata, was being performed on an opera stage of 'normalized' Czechoslovakia. Apart from the music and dance, the spoken word also played an important role and the two main figures, Joan and Brother Dominic, were performed by the actors (Jana Hlaváčková and Otakar Dadák). The text by Paul Claudel placed high literary demands on the viewer, with lyrical passages mixed with farce, pathos and grotesquely shaped aspects. This mixture was underlined by Honegger's poly-style and multi-genre music, mixing Baroque, plainchant, pop or jazz elements and forming the meaning of the text with often literal descriptiveness. ${ }^{12}$ The work has an important part for the ondes Martenot, an early electronic instrument, played at the premiere by its inventor Maurice Martenot (see HALBREICH 1999: 422-423). The non-linear fragmentary narrative with a range of symbolic moments and characters made use of a retrospective structure: the plot begins at the end of Joan's life, which is played in front of the audience's eyes and before herself as a recapitulation of key moments which all led to her burning. Joan, by means of Brother Dominic, recalls the absurd trial where the judges took the form of animals (e.g. a pig, ass or sheep), her time in prison, the game of cards which resulted in her victimisation, scenes from the time of her happy childhood in Normandy and the triumphal arrival of Dauphin Charles to the coronation in Rennes. Worthy of mention are two scenes which indicate the power of political relevance, in particular within the context of the Soviet occupation of Czechoslovakia at the end of the 1960s and the events surrounding Palach's death. The first one is the fourth scene 'Joan Given Up to the Beasts', beginning with the fanfares announcing the arrival of the court. Brother Dominic assures her that Joan's judges were not priests, not men, but beasts. If the Tiger, the Fox, and the Serpent refuse to serve as judges, the Pig offers to preside. (This is a convenient pun on the name Pierre Cauchon, the judge in Joan's trial, who was Bishop of Beauvais, one-time rector of the University of Paris, and a leader of the pro-English party in France; Cauchon is homonymous with 'cochon,' or 'pig'.) The jury consists of Sheep and the court recorder is the Ass. The trial itself is a travesty of justice. When Joan denies that she accomplished her deeds with the help of the Devil, the Pig simply orders the record to show that she has confessed. The Sheep are easily led to condemn her to death by fire. Another important part of Honegger's oratorio is the sixth scene 'The Kings, or the Invention of the Game of Cards', summarizing political

12 At its première in Basel the piece was an immediate success, with critics almost unanimous in praising a perfect cohesion between words and music. 
intrigues leading to Joan's sentence. The scene shows the mad game of European diplomacy in which the deck of cards includes four kings, four queens, and four knaves. We encounter the King of England and his consort Stupidity, the King of France and her Majesty Pride, the Duke of Burgundy and his consort Avarice. The fourth king is Death, accompanied by Her Majesty Lust. Joan herself is the merest pawn in this game of international diplomacy played for deadly stakes.

The preserved photographs and other sources from the staging do not indicate that the creators were consciously attempting a certain updating of the work. This was not necessary, however, as the sense and ideological message of Honegger's opus was immediately apparent to the viewers of the day. Honegger himself, in order to enhance the contemporary reading of the work, included a prologue later in the score in the year 1944 which makes explicit reference to the parallel between France occupied by the English and France under the rule of Nazi Germany. ${ }^{13}$ Joan's sacrifice, which is re-enacted in the main part of the oratorio, becomes thus more clearly a sacrifice for France (see KELLY 2013: 200). This parallel is recalled in the preparatory notes for the staging by the director Wasserbauer. Both periods had a great deal in common, at both time France greatly needed, for example, 'unity and courage'. ${ }^{14}$ Added in pencil by the director was 'This is the case for us at present', serving to confirm the connection between history and the present which Honegger outlined in his work and which was still valid for Czechoslovakia at the end of the 1960s. Palach's martyr's death and the consequent wave of national solidarity, which became apparent over the days of the Brno premiere of Honegger's opus ensured that the staging, even without any special efforts on the part of the authors, had an unexpected relevance.

Dana Toncrová carried out a detailed reconstruction of the staging in her Master's thesis using photographs from the archive of the National Theatre in Brno and period reviews (TONCROVÁ 2000: 74-83). Reference should be made to at least the stage design which combined an emphasis on the utilitarian character of the items used with their symbolic meaning and which allowed for a linking of the staging and concert line of the work. Vojtěch Štolfa created the simple stage design by means of platforms which divided the space into three levels arranged behind one another as performance areas. The choir was standing on the lowest in concert clothes. Certain soloists were amongst them, who would enter the play at certain points. The central part of the space, in contrast, was designated by the authors for the dance and pantomime scenes, the theatrical character of which was emphasized by stylised colourful costumes: the most distinct of these being the scene of The Game of Cards and the trial scene with caricature figures, delivering the sentence of death to Joan in grotesque animal masks. The children's choir also had costumes and performed in this part of the space. Joan and Brother Dominic were provided with a square rostrum, which the director placed in the centre of the rear part of the stage. Joan's basic di-

13 The oratorio begins with the chorus singing 'Darkness! Darkness! And France was without form and void, and darkness covered the face of the kingdom.'

14 See the legacy of Miloš Wasserbauer, Theatre History Department of the Moravian Museum in Brno, carton no. 280 . 


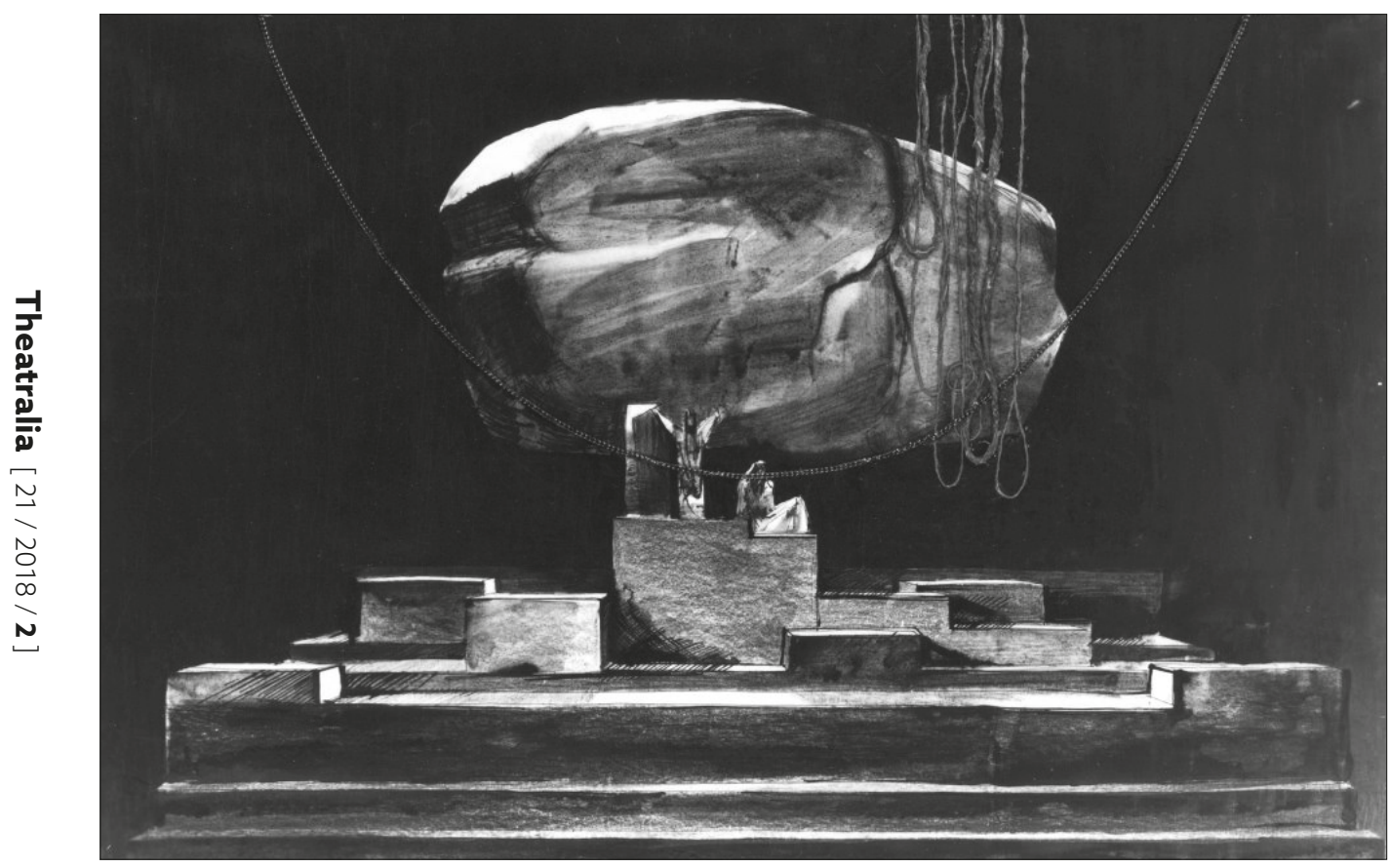

Fig. 3: A. Honegger: Joan of Arc at the Stake. National Theatre in Brno, 1969. Sketch of the set design by Vojtěch Štolfa. Archive NTB.

lemma was symbolised in the story by chains which the heroine had attached to her wrists and which reached on the other ends up to the ceiling of the stage. The snapping of the shackles at the end of the performance apparently made 'a fascinating impression' (see HEERENOVÁ 1970: 160). Three nooses hung over the head of the character with additional ropes included in the space of the stage. ${ }^{15}$ My comparison of pictures from the performance with stage designs indicates that a huge boulder was originally supposed to be floating above the heads of Joan and Dominic. Its function undoubtedly corresponded to the symbolic meaning of the majority of the other props which were used on the stage.

The work of Dana Toncrová did not explore sufficiently the preserved hand and type written materials from the legacy of Miloš Wasserbauer. ${ }^{16}$ They contain the director's extensive explanations of events linked with the Hundred Years' War and the fate of Joan of Arc (5 p.), a list of literary works on this theme (3 p.), brief biographies of Paul Claudel and Arthur Honegger (1 p.), the order of the scenes in Honegger's oratorio ( 1 p.), the characters and cast ( 1 p.), a list of specialised literature ( 1 p.) and a brief interpretation of the work, in all probability aimed at audience prior to the performance $(2$ p.). Wasserbauer mentions, among other things, the disparate character of the

15 Microphones were hung on these ropes which served to enhance the spoken recitation which had to suddenly 'compete' with the huge orchestra and the choir.

16 See note 14. 
musical tools and how the descriptiveness of music in relation to the plot was motivated by Honegger's interest in comprehensibility and accessibility for the wider 'audience masses'.

He also made mention of the game of cards as a key situation in the plot as the theme of an ordinary person at the mercy of power games was a particularly powerful motif at the time after the Soviet occupation of Czechoslovakia. The scenes in which Joan of Arc was sentenced on the basis of betrayal of her own people must have also been truly powerful. One should recall that the viewers sitting in the audience experienced a difficult time after the invasion by the troops of the Warsaw Pact, which resulted in a certain exasperation from the aggressive intervention of Russia into the free political life in Czechoslovakia and frustration from the failure of the domestic political representation that - after the so-called the Moscow Protocol - had lost the trust of the people due to their inability to fight for a free Czechoslovakia (Palach's act was intended in fact as an extreme expression of disappointed trust). Many of the viewers also remembered the Munich betrayal of only thirty years earlier - and the feelings of the people of Czechoslovakia was expressed by a well-known slogan 'About us, without us!'

The powerful impact of the performance is apparent from the recollections of participants. Particularly poignant are the recollections of the dramaturg Václav Nosek: 'We also came to know the powerful impact of this work and its healing power after fateful August 1968. /.../ And it was not only we the performers who were affected, but it was apparent from the long moments of silence after the end of each performance, as if the public was reluctant to disturb the emotional mood.' (NOSEK 1995) He added that it was impossible to avoid the criticism by functionaries (no names mentioned) that the National Theatre in Brno had put on the staging in commemoration of Jan Palach. (NOSEK 1995) Of interest is the fact that the period press also paid attention to the work. It is apparent that relatively independent discussion could still take place at the edge of the centre (the centre being Prague). The Brno daily newspaper Rovnost (Equality) by means of a reviewer wrote that, 'the moral sense of the work relates of the false judges and corrupt historians and the still-relevant historical applicability for our generation as well' (FUKAČ 1969). The reviewer of the newspaper Práce (Work) viewed the final call of the choir, echoing the Bible (John 15:13), 'Greater love has no man than he who gives his life for those he loves' as a message which obtains a particular urgency at this unquiet time in the country (TROJAN 1969).

\section{Conclusion}

If I were to summarise in conclusion the meaning of this staging, I would draw distinct attention to the dramaturgical contribution. The Brno opera presented a work which had not previously been performed on the Czechoslovak stage. The primary reason for this was the undoubted staging and interpretative demands involved with Honegger's monumental hybrid creation. The fact that Brno placed Jeanne d'Arc au bûcher into their repertoire at the time of revolutionary political changes in Czechoslovakia 
provided the story of Joan of Arc with an up-to-date message. It would be difficult to find additional stagings in the opera theatres in Czechoslovakia at the time which provided a similar powerful link with that which was actually taking place. It is extremely interesting therefore that this work remained part of the repertoire up until May of the year 1970 and was presented 12 times in all. It was not performed again until the year 1995 and this once again in Brno. Unfortunately, since this time it has returned to the Czech stage in only one other performance, and that was the performance from 2016 in the J. K. Tyl Theatre in Pilsen.

\section{Bibliography}

FUKAČ, Jiří. 1969. Dlouho očekávaná premiéra [A Long Awaited Premiere]. Rovnost 84 (2. 7. 1969): 5.

HALBREICH, Harry. 1999. Arthur Honegger (translated by Roger Nichols). Portland: Amadeus Press, 1999.

HAVLÍČKOVÁ KYSOVÁ, Šárka and SPURNÁ, Helena. 2016. Dramaturgická východiska opery Státního divadla v Brně v době působení Václava Noska a Miloše Wasserbauera [The Dramaturgy of the State Theatre Brno under Václav Nosek and Miloš Wasserbauer]. Theatralia 19 (2016): 1: 212-227.

HEERENOVÁ, Petra. 1969. Rozhovor před premiérou [Interview Before the Première]. Rovnost 84 (26. 6. 1969): 5.

HEERENOVÁ, Petra. 1970. Brněnská opera v letech 1945-1970 [The Brno Opera in 1945-1970]. Brno: Univerzita J. E. Purkyně, 1970. Master's Thesis, unpublished.

KELLY, Barbara L. 2013. Music and Ultra-modernism in France. A Fragile Consensus, 1913-1939. Woodbridge: The Boydell Press, 2013.

MEDEK, Ivan. 2005. Děkuji, mám se výborně [Thank You, I’m Doing Great]. Praha: Torst, 2005.

MUSILOVÁ, Martina. 2008. Vlivy Brechtovy divadelní poetiky na herectví Mahenovy činohry v letech 1959-1969 [Influences of Brecht's Theatre Poetics on the Acting Style of Mahen Drama Theatre In 1959-1969]. Sbornik praci Filozofické fakulty brněnské univerzity (Q) 11 (2008): 85-112.

NACHMILNEROVÁ, Eva. 2009. Duše však zabít nemohou. Ohlas činu Jana Palacha v české klasické hudbě [They Cannot Kill the Spirit. Responses to the Act of Jan Palach in Czech Classical Music]. In Michala Benešová, Petr Blažek, Patrik Eichler (eds.). Jan Palach ‘69. Praha: Filozofická fakulta UK v Praze, 2009: 223-227.

NOSEK, Václav. 1995. Jana z Arku na hranici [Joan of Arc at the Stake]. In A. Honegger: Jana z Arku na hranici. Programová brožura k inscenaci v Janáčkově divadle v Brně, premiéra 3. listopadu 1995, nestr. [A. Honegger: Joan of Arc at the Stake. Brochure for the staging in Janáček Theatre in Brno. Premiered on November 3, 1995. Unpaged.].

TONCROVÁ, Dana. 2000. Miloš Wasserbauer a jeho hledáni realistické scénické interpretace v opeře. Tvorba Miloše Wasserbauera ve Státním divadle Brno v letech 1958-1970 [Miloš Wasserbauer and His Search for Realistic Staging of Opera: the Work of Miloš Wasserbauer in the Brno State Theatre in 1958-1970]. Brno: Masarykova univerzita, 2000. Master's Thesis, unpublished. 
TROJAN, Jan. 1969. Vrcholná událost letošní operní sezóny: Jana z Arcu na hranici [Top Events from This Year's Opera Season: Joan of Arc at the Stake]. Práce 25 (4. 7. 1969): 6.

YANNAKAKIS, Ilios. 2009. Nepochopená obět Jana Palacha [The Misunderstood Victim of Jan Palach]. In Michala Benešová, Petr Blažek, Patrik Eichler (eds.). Jan Palach '69. Praha: Filozofická fakulta UK v Praze, 2009: 176-179.

\section{doc. Mgr. Helena Spurná, Ph.D.}

Department of Theatre and Film Studies

Faculty of Arts, Palacký University Olomouc, Czech Republic

helena.spurna@upol.cz

Helena Spurná (1970) graduated from Masaryk University, Brno (CZ) in 1999 (dissertation: Between Music and Theatre. Emil František Burian's Musical Theatre). She worked as an Assistant Professor at the Department of Theatre Studies of the said university from 1999 to 2001. From then on, she has a position at the Department of Theatre and Film Studies, Faculty of Arts, Palacký University, Olomouc (CZ), teaching Theatre History. She researches into Czech Modern Theatre, especially the Music Theatre. She edited a highly appreciated collection the Music Theatre as a Challenge (Praha: Národní divadlo, 2004), and authored two monographs, Emil František Burian and His Journey to Opera (2014) and Oldřich Stibor, Theatre Director and a Person (1901-1943). 